\title{
Heterogeneity of fern communities in riparian forest remnants from the South Brazilian Campos (Pampa)
}

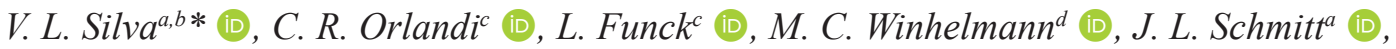 \\ C. S. Fior (D) $^{\text {and E. M. Freitas }}{ }^{c, e, f}$
}

aLaboratório de Botânica, Universidade Feevale, ERS-239, 2755, CEP 93352-000, Novo Hamburgo, RS, Brasil

bLaboratório de Acarologia, Universidade do Vale do Taquari - Univates, Av. Avelino Tallini, 171, Bairro Universitário, CEP 95900-000, Lajeado, RS, Brasil

${ }^{\mathrm{c}}$ Curso de Ciências Biológicas, Centro de Ciências Biológicas e da Saúde - CCBS, Universidade do Vale do Taquari - Univates, Av. Avelino Talini, 171, Bairro Universitário, CEP 95914-014, Lajeado, RS, Brasil

dPrograma de Pós-graduação em Fitotecnia, Universidade Federal do Rio Grande do Sul - UFRGS, Av. Bento Gonçalves, 7712, CEP 91540-000, Porto Alegre, RS, Brasil

ePrograma de Pós-graduação em Sistemas Ambientais Sustentáveis - PPGSAS, Universidade do Vale do

Taquari - Univates, Av. Avelino Talini, 171, Bairro Universitário, CEP 95914-014, Lajeado, RS, Brasil

fPrograma de Pós-graduação em Biotecnologia - PPGBiotec, Universidade do Vale do Taquari - Univates, Av. Avelino Talini, 171, Bairro Universitário, CEP 95914-014, Lajeado, RS, Brasil

*e-mail: suicinivleao@gmail.com

Received: March 11, 2019 - Accepted: June 27, 2019 - Distributed: November 30, 2020

(With 4 figures)

\begin{abstract}
Riparian forests present biotic and abiotic factors that influence environmental dissimilarity, which reflect specific fern distribution. The purpose of this this study was to evaluate the environmental heterogeneity associated to the terrestrial fern communities in riparian forest remnants in the grasslands southern half of Rio Grande do Sul state. We sampled ten $5 \times 5 \mathrm{~m}$ plots in each site (AI, AII and AIII), totaling 30 plots. In each plot, fern species were inventoried and vegetative, microclimatic and edaphic parameters were collected. A total of 24 species were surveyed in the three riparian forest remnants, distributed in 19 genera and 10 families. The Principal Components Analysis (PCA) showed that plots of AI had the highest temperature and aluminum values, while humidity was the lowest, which was reflected in the decrease of ferns richness. Soil moisture and air humidity were variables more related to the plots of AII and AII, indicating that these plants were favored in these environments. The floristic identity characteristic of each site suggests that many species are dependent to certain local environmental conditions. In this sense, even in very geographically close sites, riparian remnants deserve conservation attention, since they are capable of harboring high diversity in this grassland phytophysiognomy in southern Brazil. The results of this integrated study, with vegetation, climatic, and edaphic parameters, suggest, as expected, that ferns categorically respond to the heterogeneity shown by riparian environments, even when fragments are geographically very close to each other.
\end{abstract}

Keywords: fern diversity, riparian vegetation, environmental parameters, phytosociology, seedless vascular plants, edaphic factors.

\section{Heterogeneidade de comunidades de samambaias em remanescentes de mata ciliar nos campos (Pampa) sul do Brasil}

\section{Resumo}

As florestas ripárias apresentam fatores bióticos e abióticos que influenciam a dissimilaridade ambiental, e que refletem a distribuição específica de samambaias. O objetivo deste trabalho foi avaliar a heterogeneidade ambiental associada às comunidades de samambaias terrícolas em remanescentes de mata ciliar dos campos da metade sul do estado do Rio Grande do Sul (Pampa). Foram amostradas dez parcelas de $5 \times 5 \mathrm{~m}$ em cada sítio (AI, AII e AIII), totalizando 30 parcelas. Em cada quadro, foram inventariadas as espécies de samambaia, além de outros parâmetros vegetacionais, microclimáticos e edáficos. Um total de 24 espécies foram identificadas nos três remanescentes de mata ciliar, distribuídas em 19 gêneros e 10 famílias. A Análise de Componentes Principais (PCA) mostrou que as parcelas de AI apresentaram os maiores valores de temperatura e alumínio, enquanto a umidade foi a menor, o que se refletiu na diminuição da riqueza de samambaias. A umidade do solo e a umidade do ar foram as variáveis mais relacionadas às parcelas de AII e AIII, indicando que essas plantas foram favorecidas nesses. A identidade florística característica de 
cada local sugere que muitas espécies são dependentes de certas condições ambientais locais. Nesse sentido, mesmo em sítios geograficamente próximos, remanescentes de matas ciliares merecem atenção no que se refere a conservação, uma vez que são capazes de abrigar grande diversidade nesta fitofisionomia exclusiva do sul do Brasil. Os resultados deste estudo integrado, com parâmetros vegetacionais, climáticos e edáficos, sugerem, que as samambaias respondem categoricamente à heterogeneidade mostrada pelos ambientes ripários, mesmo quando os fragmentos estão próximos.

Palavras-chave: diversidade de samambaias, vegetação ripária, parâmetros ambientais, fitossociologia, plantas vasculares sem sementes, fatores edáficos.

\section{Introduction}

The vegetation adjacent to water bodies, known as riparian forest (Mueller, 1996), is characterized by sheltering floristic heterogeneity attributed to factors such as size of the forested riparian area, conservation state, and origin. In addition, other elements (with limited activity) influence its structure, such as water table level, topography, relief, flood regime, and edaphic characteristics (Rodrigues and Nave, 2001; Mallmann et al., 2015). Although riparian forest play an essential role in the environmental context (Ritchie and McCarty, 2003; Araujo et al., 2004; Martins, 2007) and are protected by Brazilian legislation (Brasil, 2012), they are still exploited and strongly anthropized (Martins, 2007).

Ferns are vascular plants intimately associated to more humid environments or environments that might retain water, such as riparian forests. These organisms have strong dependence on high moisture for sexual reproduction because they have flagellate gametes and external sexual fertilization (Pausas and Sáez, 2000). This is mainly due to the optimal conditions provided by these sites such as shading and constant water availability (Mallmann et al., 2015). Thus, these plants are potential bioindicators of environmental quality, since their richness and their capacity for occupying areas are mostly linked to abiotic factors (Silva et al., 2011).

The total seedless tracheophytes are estimated at 13,000 species at a global level (PPG I, 2016), and the Neotropical region is one of the richest. This is the case of Brazil, where this group is highly diversified (Hassler and Schmitt, 2016), with over 1,300 species described and distributed mostly in the southern and southeastern regions. A total of 378 species are listed in Rio Grande do Sul (JBRJ, 2018).

Several fern surveys have already been conducted in riparian forests in southern Brazil. In Rio Grande do Sul state (RS), Mallmann et al. (2015) evaluated the anthropic gradient in three riparian forest fragments of the Cadeia River; Mallmann and Schmitt (2014) evaluated three other fragments in the same river and recorded 40 species. Padoin et al. (2015), studying a fragment of a Rolante River tributary, found 65 species; Diesel and Siqueira (1991), studying three areas of the Sinos River basin, recorded 24 species; Becker et al. (2013) identified 62 species in a study conducted in the municipality of Caraá, in the Sinos River basin. However, all of them are inside the Atlantic Forest, which indicates that information about ferns in riparian forests of the grasslands southern half of $\mathrm{RS}$ is scarce or absent.
According to the Species List of the Brazilian Flora database (JBRJ, 2018), there are only 14 fern species in the Rio Grande do Sul grassland's (Pampa). This limited number might be associated to the lack of surveys. Even with the increasing number of studies addressing richness and composition of ferns in the South of Brazil, there are gaps regarding the geographical distribution of these groups, mostly in the southernmost half of Rio Grande do Sul state.

Topographic characteristics of the land, such as elevations and/or slopes, seem to be associated with moisture or soil drainage, which is also related to fertility, and consequently, will be associated with the distribution pattern and abundance of fern species (Poulsen et al., 2006). In this regard, soil offers a wide array of physico-chemical conditions such as temperature, moisture, and nutrient availability, and the earthy substrate is the most frequently used by these species (Tuomisto and Ruokolainen, 1994).

By studying the heterogeneity of fern communities in riparian forest remnants inside the Eucalyptus saligna $\mathrm{Sm}$. monoculture matrix, we expect to answer the following questions: i) Do geographically close riparian forest fragments show differences in the fern community structure? We believe riparian environments to be heterogeneous, even when they are near each other; ii) Which microclimatic variables are the most related to diversity of terrestrial ferns? We considered the highest values of relative air humidity, soil moisture, and lowest canopy openness to have higher correlation with diversity; iii) Is fragment width related to community diversity? We expected the narrower fragment to provide the less favorable conditions for the settlement of terrestrial ferns; iv) Does the edaphic composition of the three sites analyzed show differences capable of influencing diversity and community structure of ferns? We assumed that the physico-chemical composition of soil is decisive for either the occurrence or restriction of some species.

\section{Material and Methods}

\subsection{Study area}

This study was conducted in three gallery forest areas located in the municipality of Pantano Grande, Rio Grande do Sul, Brazil. Area 1 (AI) (S 30 19' 272" and W 52 28' 892"), area 2 (AII) (S 30 $10^{\circ} 714^{\prime \prime}$ and $30^{\circ} 19^{\prime} 714^{\prime \prime}$ ), and area 3 (AIII) (S 30 19'495" and W 52 30'045") (Figure 1), with 6,800,13,300, and 9,000 $\mathrm{m}^{2}$, respectively. The study areas are part of permanent preservation areas of a Forest Garden comprised of Eucalyptus saligna Smith plantations. 


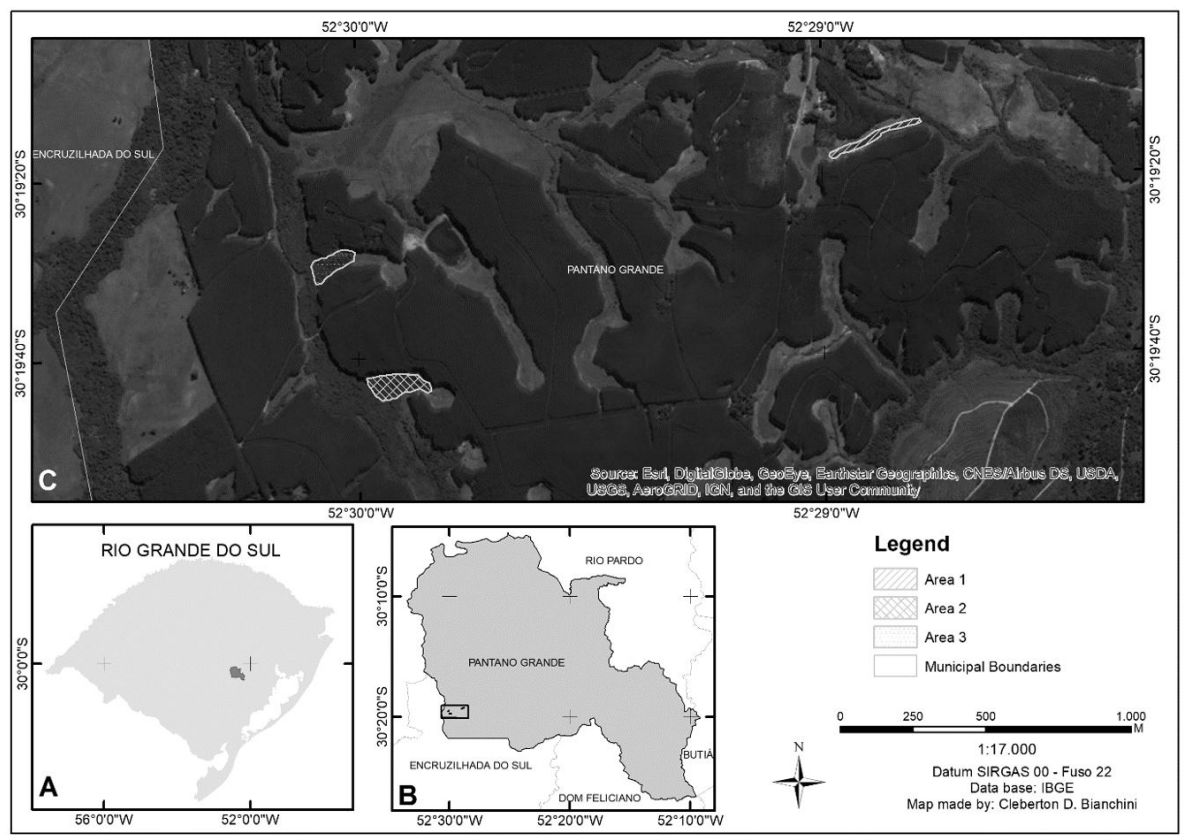

Figure 1. Map of the three areas with riparian forest fragments (A) Rio Grande do Sul state; (B) Pantano Grande city; and (C) Location of study areas.

The study sites are inserted in the grasslands southern half of RS; however, due to their proximity to the seasonal Atlantic Forest, they are characterized as ecological tension zones, with influence from these formations (Marchiori, 2004). According to Köppen-Geiger's classification, climate is Cfa type, characterized as humid, temperate, with well-defined summer, and winter seasons (Peel et al., 2007). Soil is Dystro-umbric Red-Yellow Argisol, defined as poorly drained, and is found in highly basic saturated lowland areas ( $\geq 50 \%$ ) (Streck et al., 2018).

\subsection{Phytosociological inventory}

Ferns were sampled by outlining a 250 -m transect parallel to the water mark line in each of the three riparian forest fragments. Twenty-five sampling points were assigned in each fragment, of which 10 were randomly chosen (raffled). At each raffled point, a $5 \times 5 \mathrm{~m}\left(25 \mathrm{~m}^{2}\right)$ plot was delimited, totaling $250 \mathrm{~m}^{2}$. Richness and abundance of terrestrial ferns were sampled in each plot. Species were identified with specialized bibliography, by comparing them with herbarium vouchers, and with the help of specialists. We followed the taxonomic classification of PPG I (2016) for families and genera.

For analysis and comparison of community structures of terrestrial ferns, relative density and frequency were calculated, as well as the importance value index (IVI) according to Vuono (2002), adapted by Condack and Sylvestre (2009) to this plant group.

\subsection{Biotic and abiotic variables}

Temperature, air humidity, and wind speed were recorded on a cloudless day at hourly intervals for 12 consecutive hours in the center of each plot. These climate data were measured with a portable digital thermo-hygroanemometer (Instruterm-Thal-300, model 0211). On the same day, hemispheric photos were taken at the center of each plot, using a Sony H5 camera equipped with a Raynox Digital fisheye lens, model DCR-CF 85 Pro. The camera was placed $1 \mathrm{~m}$ above the ground, leveled and pointed to the North (Garcia et al., 2007). The images were analyzed for relative canopy openness using ImageJ 1.5i. Soil moisture and depth of the litter layer were also measured at three points within each plot. Soil samplings were performed in zig-zag, with the help of a Dutch auger, at depths of 0 to $20 \mathrm{~cm}$. After that, homogenization was performed, forming three samples per site (AI, AII, and AIII); one in the upper portion of the fragment, one in the intermediate portion, and one in the final portion of each fragment. Subsequently, samples were sent for physico-chemical analyses at the Laboratory of Soils (LAS) of the Federal University of Rio Grande do Sul (UFRGS). Soil moisture content was measured using an AT Delta-T Device HH2 Moisture Meter, version 4.0. Additionally, we estimated the percentage cover of rocks, soil, herbs and leaf litter in each plot, according to the scale proposed by Braun-Blanquet (1979).

\subsection{Data analysis}

A Principal Component Analysis (PCA) was used to investigate the relationships between abiotic factors using the PAST software (Hammer et al., 2001), version 3.14, and distribution of the plots. A second PCA was performed based on physico-chemical analyses of three soil samples from each site. We performed a non-metric multidimensional scaling (nMDS) on Bray-Curtis similarity matrices of 
fern abundance data. To detect significant changes in the floristic composition among fern communities of the nMDS groups, we ran a similarity analysis (ANOSIM) with 999 permutations using p/a data. We used a similarity percentage analysis (SIMPER) to identify the fern species that contributed most with the similarity within groups, as well as with the dissimilarity between groups. All three analyses were performed using the PRIMER-E software (Clarke and Gorley, 2002), version 5.2.9.

\section{Results}

Fern survey indicated the occurrence of 24 species ( $\mathrm{AI}=8$ species, $\mathrm{AII}=16$ species, and $\mathrm{AIII}=15$ species $)$ in the three riparian forest remnants, distributed in 19 genera and 10 families. Among the three areas, the most numerous families were Pteridaceae (seven species), Thelypteridaceae (five species), and Blechnaceae (three species), while Amauropelta Kunze (4), Adiantum L. (2), and Doryopteris
J.Sm. (2) were the most abundant genera. The species shared by the three areas were Anemia phyllitidis (L.) Sw, Blechnum austrobrasilianum de la Sota, and Neoblechnum brasiliense (Desv.) Gasper \& V.A.O. Dittrich (Table 1).

In AI, Blechnum austrobrasilianum had the highest IVI (59.47\%) among the species sampled, followed by Cyathea atrovirens (Langsd. \& Fisch) Domin (10.69\%); the value of the former was six times higher than the latter due to the high number of individuals collected, and consequently, to its high density (107,920 ind ha $\left.{ }^{-1}\right)$. In addition, $B$. austrobrasilianum occurred in all plots. Rumohra adiantiformis (G. Forst.) Ching (8.49\%) was the third most important species in the community, followed by Neoblechnum brasiliense (8.22\%) (Table 2). Together, these four species represented approximately $90 \%$ of IVI, thus indicating that few species were responsible for the fern community structure in AI.

In AII, Blechnum austrobrasilianum had the highest IVI (20.22), followed by Lomaridium plumieri (Desv.)

Table 1. List of families and species of ferns sampled in the three areas of riparian forest remnants (AI, AII, and AIII) in Pantano Grande, RS.

\begin{tabular}{|c|c|c|c|}
\hline Family/species & AI & AII & AIII \\
\hline \multicolumn{4}{|l|}{ ANEMIACEAE } \\
\hline Anemia phyllitidis (L.) Sw. & $\mathrm{X}$ & $\mathrm{X}$ & $\mathrm{X}$ \\
\hline \multicolumn{4}{|l|}{ ASPLENIACEAE } \\
\hline Asplenium claussenii Hieron. & & $\mathrm{X}$ & $\mathrm{X}$ \\
\hline \multicolumn{4}{|l|}{ ATHYRIACEAE } \\
\hline Diplazium cristatum (Desr.) Alston & & $\mathrm{X}$ & \\
\hline \multicolumn{4}{|l|}{ BLECHNACEAE } \\
\hline Blechnum austrobrasilianum de la Sota & $\mathrm{X}$ & $\mathrm{X}$ & $\mathrm{X}$ \\
\hline Lomaridium plumieri (Desv.) C. Presl & $\mathrm{X}$ & $\mathrm{X}$ & \\
\hline Neoblechnum brasiliense (Desv.) Gasper \& V.A.O. Dittrich & $\mathrm{X}$ & $\mathrm{X}$ & $\mathrm{X}$ \\
\hline \multicolumn{4}{|l|}{ CYATHACEAE } \\
\hline Alsophila setosa Kaulf. & & $\mathrm{X}$ & \\
\hline Cyathea atrovirens (Langsd. \& Fisch) Domin & $\mathrm{X}$ & & \\
\hline \multicolumn{4}{|l|}{ DRYOPTERIDACEAE } \\
\hline Ctenitis submarginales (Langsd.) \& Fisch.) Ching & & $\mathrm{X}$ & \\
\hline Rumohra adiantiformis (G. Forst.) Ching & $\mathrm{X}$ & & $\mathrm{X}$ \\
\hline \multicolumn{4}{|l|}{ HYMENOPHYLLACEAE } \\
\hline Didymoglossum hymenoides (Hedw.) Desv. & & & $\mathrm{X}$ \\
\hline \multicolumn{4}{|l|}{ POLYPODIACEAE } \\
\hline Campyloneurum nitidum (Kaulf.) C. Presl. & $\mathrm{X}$ & $\mathrm{X}$ & \\
\hline \multicolumn{4}{|l|}{ PTERIDACEAE } \\
\hline Adiantopsis chlorophylla (Sw.) Fée & & & $\mathrm{X}$ \\
\hline Adiantum digitatum Hook. & & $\mathrm{X}$ & \\
\hline Adiantum raddianum C. Presl & & $\mathrm{X}$ & $\mathrm{X}$ \\
\hline Anogramma lorentzii Link. & & & $\mathrm{X}$ \\
\hline Doryopteris concolor (Langsd. \& Fisch.) Kuhn & & & $\mathrm{X}$ \\
\hline Doryopteris lorentzii (Hieron.) Diels & & $\mathrm{X}$ & $\mathrm{X}$ \\
\hline Pteris brasiliensis Raddi & & $\mathrm{X}$ & \\
\hline \multicolumn{4}{|l|}{ THELYPTERIDACEAE } \\
\hline Amauropelta amambayensis (Christ) Salino \& A.R. Sm. & & $\mathrm{X}$ & $\mathrm{X}$ \\
\hline Amauropelta recumbens (Rosenst.) Salino \& T.E.Almeida & & & $\mathrm{X}$ \\
\hline Amauropelta rivularioides (Fée) Salino \& T.E.Almeida & $\mathrm{X}$ & $\mathrm{X}$ & \\
\hline Amauropelta stierii (Rosenst.) Salino \& T.E.Almeida & & & $\mathrm{X}$ \\
\hline Goniopteris riograndensis (Lindm.) Ching & & $X$ & $\mathrm{X}$ \\
\hline Total t a & 8 & 16 & 15 \\
\hline
\end{tabular}


C. Presl (18.87), Asplenium claussenii Hieron. (16.58), and Pteris brasiliensis Raddi (8.71). The sum of the IVI of these four species was approximately $65 \%$ of the total value in this community, whereas more than $70 \%$ of the community showed IVI values lower than $6.0 \%$ (Table 3 ).

Unlike AI and AII, the species with the highest IVI in AIII were Amauropelta amambayensis (Christ) Salino \& A.R. Sm (24.01), followed by Anemia phyllitidis (22.81), Neoblechnum brasiliense (20.53), and Goniopteris riograndensis (Lindm.) Ching (4.13), and together, they accounted for more than $70 \%$ of the total community IVI. Similar to area AII, approximately $3 / 4$ of the species obtained an IVI lower than 4\% (Table 4).

A Principal Component Analysis (PCA) was performed using the plots of the three sites. The first two components explained $61.3 \%$ of the variation among plots in the areas (Figure 2). Component 1 was mostly correlated with air humidity (-0.57), temperature ( 0.51$)$, and canopy openness (0.51) and component 2 was mostly correlated with soil cover (0.64), soil moisture, and temperature (-0.29). Overall, AI had the highest temperature values, while its relative air humidity values were the lowest. AIII had high humidity values and percentage of exposed soil; however, canopy openness was similar to $\mathrm{AI}$ and AII, along the direction of the canopy openness ( $\mathrm{CO}$ ) axis. On the other hand, AII had milder temperature values, lower air humidity, a more closed canopy, and the highest percentage of rock.

Regarding the physico-chemical data of three soil samples, the first two components explained $75.6 \%$ of the variation between in the areas (Figure 3). The first

Table 2. Phytosociological parameters of the fern species sampled inside a gallery forest area - AI, along a creek in the municipality of Pantano Grande, RS.

\begin{tabular}{lccrrr}
\hline \multicolumn{1}{c}{ Species } & NI & UAI & DR & FR & IVI \\
\hline Blechnum austrobrasilianum & 2698 & 10 & 96.22 & 22.73 & 59.47 \\
Cyathea atrovirens & 26 & 9 & 0.93 & 20.45 & 10.69 \\
Rumohra adiantiformis & 30 & 7 & 1.07 & 15.91 & 8.49 \\
Neoblechnum brasiliense & 15 & 7 & 0.53 & 15.91 & 8.22 \\
Campyloneurum nitidum & 14 & 4 & 0.50 & 9.09 & 4.80 \\
Anemia phyllitidis & 11 & 4 & 0.39 & 9.09 & 4.74 \\
Lomaridium acutum & 5 & 2 & 0.18 & 4.55 & 2.36 \\
Amauropelta rivularioides & 5 & 1 & 0.18 & 2.27 & 1.23 \\
Total & 2804 & & & & \\
\hline NI Nur
\end{tabular}

$\mathrm{NI}=$ Number of individuals; UAI = Number of plots where the species occurred; DR = Relative Density; FR = Relative Frequency; IVI = Importance Value Index.

Table 3. Phytosociological parameters of the fern species sampled inside a gallery forest area - AII along a creek in the municipality of Pantano Grande, RS.

\begin{tabular}{lccccc}
\hline \multicolumn{1}{c}{ Species } & NI & UAI & DR & FR & IVI \\
\hline Blechnum austrobrasilianum & 214 & 7 & 29.16 & 11.29 & 20.22 \\
Lomaridium plumieri & 215 & 4 & 29.29 & 6.45 & 18.87 \\
Asplenium claussenii & 125 & 10 & 17.03 & 16.13 & 16.58 \\
Anemia phyllitidis & 45 & 7 & 6.13 & 11.29 & 8.71 \\
Pteris brasiliensis & 33 & 7 & 4.50 & 11.29 & 7.89 \\
Neoblechnum brasiliense & 23 & 5 & 3.13 & 8.06 & 5.60 \\
Adiantum raddianum & 12 & 4 & 1.63 & 6.45 & 4.04 \\
Alsophila setosa & 21 & 3 & 2.86 & 4.84 & 3.85 \\
Campyloneurum nitidum & 13 & 3 & 1.77 & 4.84 & 3.30 \\
Amauropelta rivularioides & 12 & 2 & 1.63 & 3.23 & 2.43 \\
Ctenitis submarginalis & 7 & 2 & 0.95 & 3.23 & 2.09 \\
Goniopteris riograndensis & 5 & 2 & 0.68 & 3.23 & 1.95 \\
Adiantum digitatum & 3 & 2 & 0.41 & 3.23 & 1.82 \\
Diplazium cristatum & 2 & 2 & 0.27 & 3.23 & 1.75 \\
Doryopteris lorentzii & 3 & 1 & 0.41 & 1.61 & 1.01 \\
Amauropelta amambayensis & 1 & 1 & 0.14 & 1.61 & 0.87 \\
Total & 734 & & & & \\
\hline NI N & & & & & \\
\hline
\end{tabular}

$\mathrm{NI}=$ Number of individuals; UAI = Number of plots where the species occurred; DR = Relative Density; FR = Relative Frequency; IVI = Importance Value Index. 
Table 4. Phytosociological parameters of the fern species sampled inside a gallery forest area - AIII along a creek in the municipality of Pantano Grande, RS.

\begin{tabular}{lccccc}
\hline \multicolumn{1}{c}{ Species } & NI & UAI & DR & FR & IVI \\
\hline Amauropelta amambayensis & 107 & 9 & 28.57 & 19.45 & 24.01 \\
Anemia phyllitidis & 75 & 6 & 28.96 & 16.67 & 22.81 \\
Neoblechnum brasiliense & 56 & 7 & 21.62 & 19.44 & 20.53 \\
Goniopteris riograndensis & 7 & 2 & 2.7 & 5.56 & 4.13 \\
Adiantum raddianum & 5 & 2 & 1.93 & 5.56 & 3.74 \\
Amauropelta recumbens & 12 & 1 & 4.63 & 2.78 & 3.71 \\
Asplenium claussenii & 2 & 2 & 0.77 & 5.56 & 3.16 \\
Blechnum autrobrasilianum & 7 & 1 & 2.7 & 2.78 & 2.74 \\
Anogramma lorentzii & 5 & 1 & 1.93 & 2.78 & 2.35 \\
Adiantopsis chlorophylla & 5 & 2 & 1.54 & 2.78 & 2.16 \\
Doryopteris lorentzii & 4 & 1 & 1.54 & 2.78 & 2.16 \\
Rumohra adiantiformis & 3 & 1 & 1.16 & 2.78 & 1.97 \\
Amauropelta stierii & 2 & 1 & 0.77 & 2.78 & 1.77 \\
Doryopteris concolor & 1 & 1 & 0.39 & 2.78 & 1.58 \\
Didymoglossum hymenoides & 1 & 1 & 0.39 & 2.78 & 1.58 \\
Total & 292 & & & &
\end{tabular}

$\mathrm{NI}=$ Number of individuals; UAI = Number of plots where the species occurred; DR = Relative Density; FR = Relative Frequency; IVI = Importance Value Index.

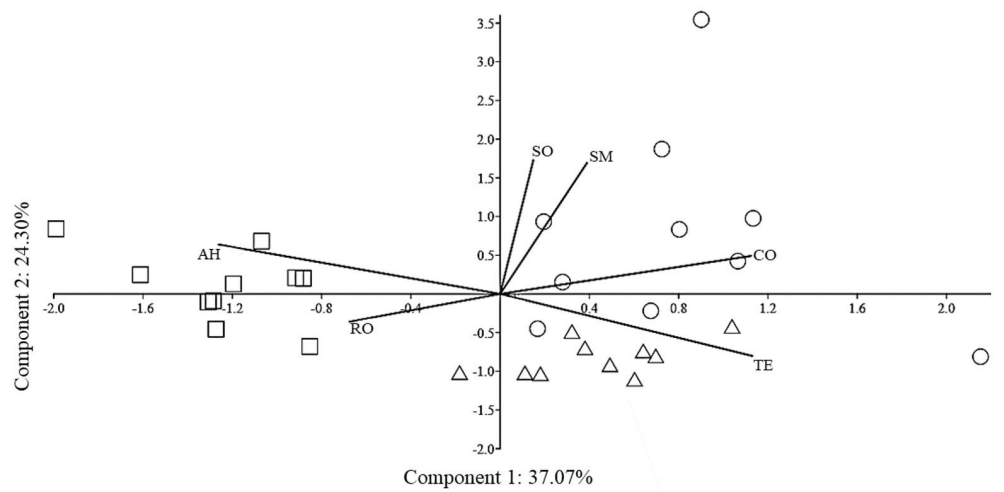

Figure 2. Principal component analysis (PCA) of sample plots from three sites of riparian forest remnants, $A I=\triangle ; A I I=\square$, and $\mathrm{AIII}=\mathrm{O} . \mathrm{AH}=$ Air humidity $(\%) ; \mathrm{CO}=$ Canopy openness $(\%) ; \mathrm{RO}=$ Rock cover $(\%)$; $\mathrm{SM}=$ Soil moisture $(\%)$; $\mathrm{SO}=$ Soil cover $(\%)$; and $\mathrm{TE}=$ Temperature $\left({ }^{\circ} \mathrm{C}\right)$. Components are expressed by their percentage of explained variation.

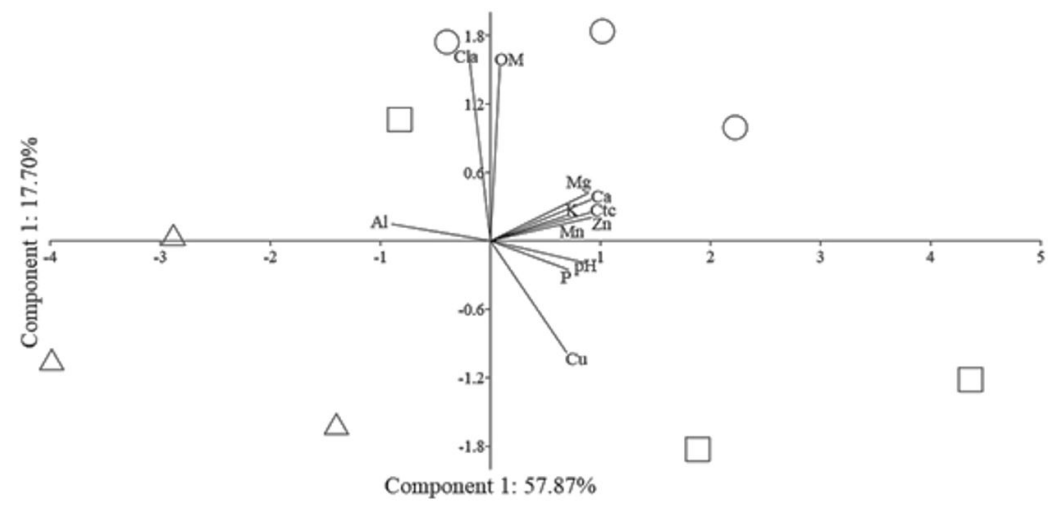

Figure 3. Principal component analysis (PCA). Physico-chemical analysis of three soil samples from each of the three sites, $\mathrm{AI}=\triangle$; $\mathrm{AII}=\square$, and $\mathrm{AIII}=0$. Clay $(\mathrm{Cla}) ; \mathrm{pH}$; Cation exchange capacity $(\mathrm{CTC})$; Organic matter $(\mathrm{OM})$; exchangeable cations (Al, K, Mg, Ca e Mn); copper (Cu); zinc ( $\mathrm{Zn})$, and phosphorus (P). Components are expressed by their percentage of explained variation. 
component was more correlated with capacity of cation exchange (0.359), calcium (0.356), and zinc (0.352) and the second one was more correlated with clay $(0.637)$, organic matter (0.597), and copper (0.381). In general, AI tended to have higher aluminum values than the other sites, as shown in the graph. $\mathrm{P}, \mathrm{pH}$, and $\mathrm{Cu}$ were more related to AII, clay and organic matter were more correlated to AIII.

The nMDS analysis confirmed the existence of three distinct groups, formed by the plots of each area. The stress value was 0.13 , suggesting an excellent ordination. This value was confirmed by the ANOSIM analysis ( $\mathrm{R}$ global $=0.763$, $p=0.001$ ), which shows that the three areas (AI, AII, and AIII) have different fern communities. The highest difference among the areas occurred between plots in AI and AIII ( $\mathrm{R}=0.901, p=0.001)$; on the other hand, this difference was lower between AI and AII $(\mathrm{R}=0.805, p=0.001)$. The lowest value occurred between $\mathrm{AI}$ and $\mathrm{AIII}(\mathrm{R}=0.552, p=0.001)$, showing that AI was the most structurally heterogeneous among the study areas (Figure 4).

In AI, there was a high similarity between plots (74\%), where Blechnum austrobrasilianum alone was the main

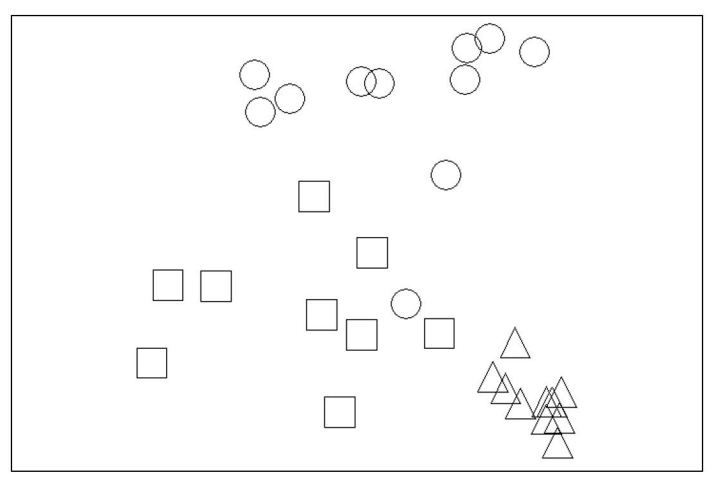

Figure 4. Graphic representation of the distribution derived from the non-metric multidimensional scaling analysis (nMDS) based on fern species abundance from three sites of riparian forest remnants in Pantano Grande, Rio Grande do Sul $(\triangle=\mathrm{A} 1 ; \square=\mathrm{A} 2$; and $\bigcirc=\mathrm{A} 3)$. Stress value $=0.13$. responsible for this similarity. In AII, five species were mostly responsible for the similarity of $28 \%$ among the plots; of those, Asplenium claussenii and B. austrobrasilianum had the highest contribution. On the other hand, a $25 \%$ percentage of similarity between plots was observed in AIII, with higher contribution of four species, among which Anemia phyllitidis and Neoblechnum brasiliense were the main ones (Table 5).

In the comparative analysis of differences among sites, they were observed to have a difference higher than $88 \%$, and the highest contribution was from the species Blechnum austrobrasilianum. Dissimilarities found between AI and AII occurred only for three species, whereas this value decreased to only two species between AI and AIII, and 10 species accounted for the dissimilarity between AI and AIII (Table 6).

Soil nutrients varied among sites, mostly phosphorus and potassium contents, which were higher in AII. On the other hand, AI had the most acidic $\mathrm{pH}$, and also the lowest percentage of organic matter, as well as the lowest availability of the other nutrients analyzed (P, K, Ca, Mg, Zn, Cu, Mn). However, it was the site with the highest availability of aluminum. Sites AII and AIII showed very similar nutrient availability patterns (except for $\mathrm{P}$ and $\mathrm{K}$ ), $\mathrm{pH}$, and percentage of organic matter (Table 7).

\section{Discussion}

The results shown in this study debunk the fern richness postulated for the grasslands southern half of RS. According to Flora do Brazil (2020 under construction), this region has only 15 species of ferns; however, richness in only $750 \mathrm{~m}^{2}$ in the present study exceeded what has been described for the grassland physiognomy by more than $30 \%$, thus indicating that the values recorded for this location lack studies and publications that might support its actual richness (JBRJ, 2018).

The great majority of studies on plant communities conducted in areas of the grasslands southern half of RS are restricted to wild and shrub species of angiosperms and indicate a diversity higher than 2,200 plant species and approximately $40 \%$ of endemism. This diversity, however, is still unknown, and it has been going through a historical process of disfigurement with the introduction of cattle,

Table 5. Similarity of fern communities (SIMPER based on Bray-Curtis similarity matrices) in three riparian forest remnants among all plots within sites denominated: AI, AII, AIII, and contribution percentage of each species to the similarity on their respective site.

\begin{tabular}{lccc}
\hline & AI & AII & AIII \\
\hline Similarity among the plots (\%) & 73.94 & 28.19 & 24.87 \\
\hline \multicolumn{1}{c}{ Species } & \multicolumn{3}{c}{ \% contribution of each species* } \\
\hline Amauropelta amambayensis & - & - & 16.07 \\
Anemia phyllitidis & - & 5.58 & 34.36 \\
Asplenium claussenii & - & 45.04 & - \\
Blechnum austrobrasilianum & 97.76 & 22.84 & - \\
Lomaridium acutum & - & 15.97 & - \\
Neoblechnum brasiliense & - & - & 29.8 \\
Pteris brasiliensis & - & 3.41 & 15.76 \\
\hline
\end{tabular}

Cut off for low contributions: $90.00 \% *$. 
Table 6. Dissimilarity among the fern communities (SIMPER based on the Bray-Curtis similarity matrices) of three remnants of riparian forest: AI, AII, AIII, and contribution percentage of each species to the difference among the sites.

\begin{tabular}{|c|c|c|c|}
\hline \multirow{2}{*}{$\begin{array}{l}\text { Dissimilarity among the Sites } \\
(\%)\end{array}$} & AI and AII & AI and AIII & AII and AIII \\
\hline & 88.14 & 95.27 & 88.65 \\
\hline Species & \multicolumn{3}{|c|}{ \% contribution of each species* } \\
\hline Anemia phyllitidis & - & 2.87 & 9.59 \\
\hline Adiantum raddianum & - & - & 1.69 \\
\hline Alsophila setosa & - & - & 2.29 \\
\hline Amauropelta amambayensis & - & - & 7.85 \\
\hline Amauropelta recumbens & - & - & 1.7 \\
\hline Asplenium claussenii & 4.88 & - & 18.79 \\
\hline Blechnum austrobrasilianum & 78.55 & 87.25 & 19.97 \\
\hline Lomaridium plumieri & 7.23 & - & 18.55 \\
\hline Neoblechnum brasiliense & - & - & 7.05 \\
\hline Pteris brasiliensis & - & - & 2.87 \\
\hline
\end{tabular}

Cut off for low contributions: $90.00 \% *$.

Table 7. Edaphic factors of the three areas analyzed (AI, AII and AIII).

\begin{tabular}{lcrr}
\hline \multicolumn{1}{c}{ Edaphic Factors } & AI & AII & AIII \\
\hline $\mathrm{Arg}(\%)$ & $35.33 \pm 2.31$ & $35.33 \pm 4.16$ & $39.33 \pm 1.5$ \\
$\mathrm{MO}(\%)$ & $2.73 \pm 0.38$ & $2.86 \pm 0.49$ & $3.93 \pm 0.61$ \\
$\mathrm{pH}$ & $4.23 \pm 0.15$ & $4.56 \pm 0.50$ & $4.56 \pm 0.32$ \\
$\mathrm{P}\left(\mathrm{mg} / \mathrm{dm}^{3}\right)$ & $2.96 \pm 0.55$ & $76 \pm 34.07$ & $9.3 \pm 2.49$ \\
$\mathrm{~K}\left(\mathrm{mg} / \mathrm{dm}^{3}\right)$ & $44.66 \pm 34.95$ & $100.33 \pm 43.09$ & $60.33 \pm 3.79$ \\
$\mathrm{Al}\left(\mathrm{cmolc} / \mathrm{dm}^{3}\right)$ & $1.96 \pm 0.49$ & $0.9 \pm 0.98$ & $0.76 \pm 0.74$ \\
$\mathrm{Ca}\left(\mathrm{cmol} / \mathrm{dm}^{3}\right)$ & $0.6 \pm 0.20$ & $5.1 \pm 3.74$ & $5.36 \pm 2.76$ \\
$\mathrm{Mg}\left(\mathrm{cmolc} / \mathrm{dm}^{3}\right)$ & $0.46 \pm 0.06$ & $1.2 \pm 0.60$ & $1.53 \pm 0.67$ \\
$\mathrm{Zn}\left(\mathrm{cmolc} / \mathrm{dm}^{3}\right)$ & $1.26 \pm 0.21$ & $2.7 \pm 0.87$ & $2.26 \pm 0.55$ \\
$\mathrm{Cu}\left(\mathrm{cmolc} / \mathrm{dm}^{3}\right)$ & $0.93 \pm 0.23$ & $1.63 \pm 0.72$ & $1.03 \pm 0.21$ \\
$\mathrm{Mn}\left(\mathrm{cmolc} / \mathrm{dm}^{3}\right)$ & $26.66 \pm 18.50$ & $48 \pm 11.53$ & $33 \pm 5.20$ \\
$\mathrm{CTC}(\%)$ & $13.66 \pm 4.73$ & $41.33 \pm 25.03$ & $44.66 \pm 15.37$ \\
\hline
\end{tabular}

Mean values and standard deviation ( \pm ) for clay (Cla); $\mathrm{pH}$; cation exchange capacity (CTC); organic matter (OM); exchangeable cations ( $\mathrm{Al}, \mathrm{K}, \mathrm{Mg}, \mathrm{Ca}$, and $\mathrm{Mn})$; copper $(\mathrm{Cu})$; zinc $(\mathrm{Zn})$, and phosphorus $(\mathrm{P})$ for the three studied segments (AI, AII, AIII in Pantano Grande, RS, Brazil). Mean \pm standard deviation.

soy and rice crops, and forestry (Boldrini et al., 2010). Confirming the negligence with the fern community, none of the studies which indicate the total value of vascular species includes this group; and knowledge is even scarcer when regarding riparian forests. However, the fact that riparian forests are not being spared in the anthropic process is unsettling, as is the fact that the community structure of associated ferns follow the conservation state of these forests (Mallmann et al., 2015). Such situation is alarming because it has been endangering species that are yet to be known.

Exclusive species and higher floristic heterogeneity and structure in AII and AIII (Table 1) show that fern communities at these sites have a more equitable distribution, with a higher number of rare species and species with low abundance (Magurran, 1988). This might be related to nutrient availability, since these species occurred in the two areas with higher nutrient availability, which means they are likely more demanding species, since they were not recorded in AI, even if the edaphic analysis per se hasn't been the only factor capable of explaining the plant heterogeneity found. The AII site is the one with the most conserved tree vegetation, therefore the soil fertility presents a constant maintenance, which may be higher in comparison to other sites. In addition, presents the largest area and the highest slopes among all sites, and by leaching processes, can favor the availability of $\mathrm{P}$ and $\mathrm{K}$ in this place (Table 7).

Sites AI and AIII showed six exclusive species, which represents approximately $40 \%$ of the exclusive community. AI, on the other hand, had only Cyathea atrovirens (Langsd. \& Fisch) Domin as exclusive species, which is known to have its growth favored by open and sunnier environments (Lehn and Leuchtenberge, 2008) compared to environments with more closed canopy (Schmitt and Windisch, 2012). Still according to Lorscheitter et al. (1999), this species prefers open and illuminated environments, such as degraded areas or forest clearings. Therefore, the analysis of soil from this site showed low fertility, low $\mathrm{pH}$, and the highest $\mathrm{Al}$ content. Hence, the fact that this species occurred in this environment might indicate that it is adapted to low soil fertility. This fact has already been pointed out in the 
study by Silva et al. (2013), who associated the occurrence of certain species in fragments belonging to the Atlantic Forest in $\mathrm{RS}$ to the occurrence of certain mineral elements in the soil. Blechnaceae occurred in all sites, thus suggesting that the species found in the present study are not as demanding regarding the abiotic factors found. Even so, AI had a value of Blechnum autrobrasilianum 10 times higher than AII and AIII, which had only seven individuals. According to Kazmirczak (1999), it is an uncommon species in the forest interior, and it occurs in well-drained environments. Although AI has lower richness than the others, some species derived from this site are naturally associated to more open, drier, and hotter environments.

Silva and Schmitt (2015) observed a relationship between canopy openness and fern richness, with more closed environments having a higher number of species. This was also observed in the present study, as AI had the most exposed, and consequently, the hottest plots. These two factors might decrease the occurrence of species that do not tolerate high temperatures (Silva et al., 2011, 2018) and exposure to sunlight (Grime, 1985), and consequently, might select those that are more tolerant to these environments, thus maximizing their occurrence in terms of number of individuals.

As AI was narrower than the other sites, the edge effect might be higher than in the others. According to Kapos (1989), Murcia (1995), and Laurance (1997), air temperature is one of the most decisive factors for edge effects. Along with temperature, higher wind velocity, lower air humidity, lower percentages of soil moisture are pointed out as stressing and restrictive factors for the occurrence of ferns in environments under the edge effect (Silva et al., 2011, 2017, 2018; Silva and Schmitt, 2015).

The barrier created by fragmentation processes and decrease in natural areas might create, even if artificially, ideal environments for less demanding species, which in turn, have their development maximized by the decrease in interspecific competitions, or quality of photosynthetically active radiation, for instance. The edge effect may lead to the replacement of more susceptible species, which demand wetter and shadier conditions, for more tolerant species (Pereira et al., 2014).

Most species found at the sites of this study were assigned to different genera, thus indicating that they are phylogenetically different (Table 1). Magurran (2004) considers that species distributed in many genera have higher phylogenetic diversity compared to species of the same genus. The more phylogenetically distinct the species, the higher is the diversity in a community (Cianciaruso et al., 2009). The more heterogeneous are the conditions and resources at a site, the higher its functional diversity might be, which supports the community ecological stability due to resources and competition (Cardinale et al., 2011).

Although geographically close, the three riparian forest fragments evaluated have important differences regarding forest structure, both in biotic and abiotic aspects; therefore, their conservation and maintenance are essential for the preservation of the group of ferns. According to
Mallmann et al. (2015), these plants might be important indicators of environmental quality of riparian forests and their community structure might be simplified according to the anthropization degree of the environment where they are inserted.

Thus, according to the reports by Rodrigues and Gandolfi (2000), outlining recovery strategies in riparian environments contributes to building knowledge on the complexity of structural phenomena that involve these formations. In this regard, it is essential to know where these riparian forests are located and what are the stressors surrounding it. That might decrease the potential of the fragment for maintaining the ideal conditions for establishment of associated ferns, after all, these organisms have been suggested as indicators of environmental changes and forest integrity (Bergeron and Pellerin, 2014; Silva et al., 2018). E. saligna exerts an allelopathic effect on other plants, and according to Lisanework and Michelsen (1993), it has the capacity to significantly reduce the germination and elongation of the roots. Although this deleterious effect was not considered in this study, it is fundamental to explore these effects of exotic monocultures close to riparian environments.

\section{Conclusions}

The results of this integrated study, with vegetation, climatic, and edaphic parameters, suggest, as expected, that ferns categorically respond to the heterogeneity shown by riparian environments, even when fragments are geographically very close to each other. Furthermore, fern communities follow this process of increased abiotic pressures (lower humidity, higher light intensity, and higher temperatures), intensified by anthropic factors such as decreased forest areas, and this reaffirms their potential as indicators both of preserved environments and of environments under human impact. This is the first study in the grasslands southern half of RS to establish an integrated relationship using ferns as indicators of environmental heterogeneity in riparian forests. Further studies should be conducted to better characterize these extremely diverse and neglected remnants, using ferns as a tool to assess environmental quality and heterogeneity of riparian environments in the grassland's southern half of Rio Grande do Sul, Brazil.

\section{Acknowledgements}

This study was supported by Coordenação de Aperfeiçoamento de Pessoal de Nível Superior (CAPES) [Postdoctoral scholarship CAPES $n^{\circ}$. 1805977 awarded to VLS], and Conselho Nacional de Desenvolvimento Científico e Tecnológico (CNPq) [scholarship no . 17659/2015-0 awarded to $\mathrm{CRO}$ ], and Fundação de Amparo à pesquisa do Estado do Rio Grande do Sul (FAPERGS) [scholarship $\mathrm{n}^{\circ}$. 0489-2551/16-2 and 17/2551-0000219-9 awarded to CRO]. We thank CMPC Celulose Riograndense, Universidade do Vale do Taquari - Univates and Universidade Feevale for all logistic and structural support. 


\section{References}

ARAUJO, M.M., LONGHI, S.J., BARROS, P.L.C. and BRENA, D.A., 2004. Caracterização da chuva de sementes, banco de sementes do solo e banco de plântulas em Floresta Estacional Decidual Ripária Cachoeira do Sul, RS, Brasil. Scientia Forestalis, vol. 66, pp. 128-141.

BECKER, D.F.P., CUNHA, S., GOETZ, M.N.B., KIELINGRUBIO, M.A. and SCHMITT, J.L., 2013. Florística de samambaias e licófitas em fragmento florestal da bacia hidrográfica do Rio dos Sinos, Caraá, RS, Brasil. Pesquisas Botânica, vol. 64, pp. 273-284.

BERGERON, A. and PELLERIN, S., 2014. Pteridophytes as indicators of urban forest integrity. Ecological Indicators, vol. 38, pp. 40-49. http://dx.doi.org/10.1016/j.ecolind.2013.10.015.

BOLDRINI, I.I., FERREIRA, P.M.A., ANDRADE, B.O., SCHNEIDER, A.A., SETUBAL, R.B., TREVISAN, R. and FREITAS, E.M., 2010. Bioma Pampa: diversidade florística e fisionômica. Porto Alegre: Palotti, $64 \mathrm{p}$.

BRASIL, 2012 [viewed 11 March 2019]. Lei no 12.651, de 25 de maio de 2012. Dispõe sobre a proteção da vegetação nativa; altera as Leis $n^{\circ}$ S 6.938, de 31 de agosto de 1981, 9.393, de 19 de dezembro de 1996, e 11.428, de 22 de dezembro de 2006; revoga as Leis $n^{\circ} S 4.771$, de 15 de setembro de 1965, e 7.754, de 14 de abril de 1989, e a Medida Provisória $n^{\circ}$ 2.166-67, de 24 de agosto de 2001; e dá outras providências [online]. Diário Oficial da República Federativa do Brasil, Brasilia, 28 de maio. Available from: http://www.planalto.gov.br/ccivil_03/_ato20112014/2012/lei/112651.htm

BRAUN-BLANQUET, J., 1979. Fitosociología: bases para el estudio de las comunidades vegetales. Madrid: H. Blume, 820 p.

CARDINALE, B.J., MATULICH, K.L., HOOPER, D.U., BYRNES, J.E., DUFFY, E., GAMFELDT, L., BALVANERA, P., O'CONNOR, M. and GONZALEZ, A., 2011. The functional role of producer diversity in ecosystems. American Journal of Botany, vol. 98, no. 3, pp. 572-592. http://dx.doi.org/10.3732/ ajb.1000364. PMid:21613148.

CIANCIARUSO, M.V., BATALHA, M.A., GASTON, K.J. and PETCHEY, O.L., 2009. Including intraspecific variability in functional diversity. Ecology, vol. 90, no. 1, pp. 81-89. http:// dx.doi.org/10.1890/07-1864.1.

CLARKE, K.R. and GORLEY, R.N., 2002. Primer 5.2.9: user manual/tutorial, PRIMER- E91. Plymouth: PRIMER-e.

CONDACK, J.P.S. and SYLVESTRE, L.S. 2009. Structure of fern community in the high mountain forest of Itatiaia National Park, Brazil. In: S.C. VERMS, S.P. KHULLAR and H.K. CHEEMA, eds. Perspective in pteridophytes. Lucknow: Bishen Singh Mahendra Pal Singh, pp. 113-126.

DIESEL, S. and SIQUEIRA, J.C., 1991. Estudo fitossociológico herbáceo/arbustivo da mata ripária da bacia hidrográfica do rio dos Sinos, Rio Grande do Sul. Pesquisas, Botânica, vol. 42, pp. 205-257.

GARCIA, L.C., REZENDE, M.Q., PIMENTA, M.A., MACHADO, R.M. and LEMOS-FILHO, J.P., 2007. Heterogeneidade do dossel e quantidade de luz no recrutamento do sub-bosque de uma mata ciliar no Alto São Francisco, Minas Gerais: análise através de fotos hemisféricas. Revista Brasileira de Biociências, vol. 5, pp. 99-101.

GRIME, J.P., 1985. Towards a functional description of vegetation. In: J. WHITE, ed. The population structure of vegetation. Dordrecht:
Dr. W. Junk, p. 503-514. http://dx.doi.org/10.1007/978-94-0095500-4_21.

HAMMER, Ø., HARPER, D.A.T. and RYAN, P.D., 2001 [viewed 26 April 2018]. PAST: Paleontological Statistics package for education and data analysis. Paleontologia Electronica [online], vol. 4, pp. 1-9. Available from: http://folk.uio.no/ohammer/past/

HASSLER, M. and SCHMITT, B., 2016 [viewed 26 September 2018]. Checklist of ferns and lycophytes of the World [online]. Available from: https://worldplants.webarchiv.kit.edu/ferns/

JARDIM BOTÂNICO DO RIO DE JANEIRO - JBRJ, 2018 [viewed 26 April 2018]. Flora do Brasil 2020 under construction [online]. Rio de Janeiro: JBRJ. Available from: http://floradobrasil. jbrj.gov.br/

KAPOS, V., 1989. Effects of isolation on the water status of forest patches in the Brazilian Amazon. Journal of Tropical Ecology, vol. 5, no. 2, pp. 173-185. http://dx.doi.org/10.1017/ S0266467400003448.

KAZMIRCZAK, C., 1999. A família Blechnaceae (Presl) Copel. (Pteridophyta) no Rio Grande do Sul. Porto Alegre: Instituto de Biociências, Universidade Federal do Rio Grande do Sul, 153 p. Master's Thesis.

LAURANCE, W.F., 1997. Hyper-disturbed parks: edge effects and the ecology of isolated rain forest reserves in tropical Australia. In: W.F. LAURANCE and R.O. BIERREGAARD, eds. Tropical forest remnants: ecology, management, and conservation of fragmented landscape. Chicago: University of Chicago Press, pp. 71-83.

LEHN, C.R. and LEUCHTENBERGE, C., 2008. Resistência ao fogo em uma população de Cyathea atrovirens (Langsd. \& Fisch.) Domin (Cyatheaceae) no Estado do Rio Grande do Sul, Brasil. Biotemas, vol. 21, no. 3, pp. 15-21. http://dx.doi. org/10.5007/2175-7925.2008v21n3p15.

LISANEWORK, N. and MICHELSEN, A., 1993. Allelopathy in agroforestry systems: the effects of leaf extracts of Cupressus lusitania and Eucaliptus spp. on four ethiopian crops. Agroforestry Systems, vol. 21, no. 1, pp. 63-74. http://dx.doi.org/10.1007/ BF00704926.

LORSCHEITTER, M.L., ASHRAF, A.R., WINDISCH, P.G. and MOSBRUGGER, V., 1999. Sonder-Abdruck aus Palaeontographica Beiträge zur Naturgeschichte der Vorzeit. Part II. Pteridophyte spores of Rio Grande do Sul flora, Brazil. Stuttgart: Schweizerbart'sche Verlagsbuchhandlung, 96 p.

MAGURRAN, A.E., 1988. Ecological diversity and its measurement. Princeton: Princeton University Press, 192 p. http:// dx.doi.org/10.1007/978-94-015-7358-0.

MAGURRAN, A.E., 2004. Measuring biological diversity. Oxford: Blackwell, $256 \mathrm{p}$

MALLMANN, I.T. and SCHMITT, J.L., 2014. Riqueza e composição florística da comunidade de samambaias na mata ciliar do Rio Cadeia, Rio Grande do Sul, Brasil. Ciência Florestal, vol. 24, no. 1, pp. 97-109. http://dx.doi.org/10.5902/1980509813327.

MALLMANN, I.T., SILVA, V.L. and SCHMITT, J.L., 2015. Estrutura comunitária de samambaias em mata ciliar: avaliação em gradiente de antropização. Revista Ambiente \& Água, vol. 11, no. 1, pp. 110-124. http://dx.doi.org/10.4136/ambi-agua.1717.

MARCHIORI, J.N.C., 2004. Fitogeografia do Rio Grande do Sul: enfoque histórico e sistemas de classificação. Porto Alegre: EST Edições, 118 p. 
MARTINS, S.V., 2007. Recuperação de matas ciliares. Viçosa; Aprenda Fácil, 255 p.

MUELLER, C.C., 1996. Gestão de matas ciliares. In: I.V. LOPES, ed. Gestão ambiental no Brasil: experiência e sucesso. Rio de Janeiro: Fundação Getúlio Vargas, pp. 185-214.

MURCIA, C., 1995. Edge effects in fragmented forests: implications for conservation. Trends in Ecology \& Evolution, vol. 10, no. 2, pp. 58-62. http://dx.doi.org/10.1016/S0169-5347(00)88977-6. PMid:21236953.

PADOIN, T.O.H., GRAEFF, V., SILVA, V.L. and SCHMITT, J.L., 2015. Florística e aspectos ecológicos das samambaias e licófitas da mata ciliar de um afluente do Rio Rolante no Sul do Brasil. Pesquisas Botânica, vol. 68, pp. 335-348.

PAUSAS, J.G. and SÁEZ, L., 2000. Pteridophyte richness in the NE Iberian Peninsula: biogeographic patterns. Plant Ecology, vol. 148, no. 2, pp. 195-205. http://dx.doi.org/10.1023/A:1009899615852.

PEEL, M.C., FINLAYSON, B.L. and MCMAHON, T.A., 2007. Updated world map of the Köppen-Geiger climate classification. Hydrology and Earth System Sciences, vol. 11, no. 5, pp. 16331644. http://dx.doi.org/10.5194/hess-11-1633-2007.

PEREIRA, A.F.N., SILVA, I.A.A., SANTIAGO, A.C.P. and BARROS, I.C.L., 2014. Efeito de borda sobre a comunidade de samambaias em fragmento de Floresta Atlântica (Bonito, Pernambuco, Brasil). Interciencia, vol. 39, no. 4, pp. 281-287.

POULSEN, A.D., TUOMISTO, H. and BALSLEV, H., 2006. Edaphic and floristic variation within a 1-ha plot of lowland Amazonian rain forest. Biotropica, vol. 38, no. 4, pp. 468-478. http://dx.doi.org/10.1111/j.1744-7429.2006.00168.x.

PTERIDOPHYTE PHYLOGENY GROUP - PPG I, 2016. A community-derived classification for extant lycophytes and ferns. Journal of Systematics and Evolution, vol. 54, no. 6, pp. 563-603. http://dx.doi.org/10.1111/jse.12229.

RITCHIE, J.C. and MCCARTY, G.W., 2003. ${ }^{137} \mathrm{Cs}$ and soil in a small agricultural watershed. Soil \& Tillage Research, vol. 69, no. 1-2, pp. 45-51. http://dx.doi.org/10.1016/S0167-1987(02)00127-7.

RODRIGUES, R.R. and GANDOLFI, S., 2000. Conceitos, tendências e ações para a recuperação de florestas ciliares. In: R.R. RODRIGUES and H.F. LEITÃO FILHO, eds. Matas ciliares: conservação e recuperação. São Paulo: Edusp, pp. 233-247.

RODRIGUES, R.R. and NAVE, A.G., 2001. Heterogeneidade florística das matas ciliares. R.R. RODRIGUES and H.F. LEITÃO
FILHO, eds. Matas ciliares: conservação e recuperação. São Paulo: Edusp, pp. 45-71.

SCHMITT, J.L. and WINDISCH, P.G., 2012. Caudex growth and phenology of Cyathea atrovirens (Langsd. \& Fisch.) Domin (Cyatheaceae) in secondary forest, southern Brazil. Brazilian Journal of Biology $=$ Revista Brasileira de Biologia, vol. 72, no. 2, pp. 397-405. http://dx.doi.org/10.1590/S1519-69842012000200023. PMid:22735150

SILVA, I.A.A., PEREIRA, A.F.N. and BARROS, I.C.L., 2011. Edge effects on fern community in an Atlantic Forest remnant of Rio Formoso, PE, Brazil. Brazilian Journal of Biology $=$ Revista Brasileira de Biologia, vol. 71, no. 2, pp. 421-430. http://dx.doi. org/10.1590/S1519-69842011000300011. PMid:21755159.

SILVA, V.L. and SCHMITT, J.L., 2015. The effects of fragmentation on Araucaria forest: analysis of the fern and lycophyte communities at sites subject to different edge conditions. Acta Botanica Brasílica, vol. 29, no. 2, pp. 223-230. http://dx.doi. org/10.1590/0102-33062014abb3760.

SILVA, V.L., MALLMANN, I.T., CUNHA, S. and SCHMITT, J.L., 2017. Impacto do efeito de borda sobre a comunidade epifíticas em floresta com Araucária. Revista Brasileira de Ciências Ambientais, vol. 45, no. 45, pp. 19-32. http://dx.doi. org/10.5327/Z2176-947820170229.

SILVA, V.L., MEHLTRETER, K. and SCHMITT, J.L., 2018. Ferns as potential ecological indicators of edge effects in two types of Mexican forests. Ecological Indicators, vol. 93, pp. 669-676. http://dx.doi.org/10.1016/j.ecolind.2018.05.029.

SILVA, V.L., ROCHA, L.D., COELHO, O.G.W. and SCHMITT, J.L., 2013. Heterogeneidade florística e edáfica de duas assembleias de samambaias na Floresta Atlântica do Estado do Rio Grande do Sul. Pesquisas Botânica, vol. 64, pp. 285-296.

STRECK, E.V., KÄMPF, N., DALMOLIN, R.S.D., KLAMT, E., NASCIMENTO, P.C., GIASSON, E. and PINTO, L.F.S., 2018. Solos do Rio Grande do Sul. 3. ed. Porto Alegre: Emater/ RS-Ascar, $252 \mathrm{p}$.

TUOMISTO, H. and RUOKOLAINEN, K., 1994. Distribution of Pteridophyta and Melastomataceae along an edaphic gradient in an Amazonian rain-forest. Journal of Vegetation Science, vol. 5, no. 1, pp. 25-34. http://dx.doi.org/10.2307/3235634.

VUONO, Y.S., 2002. Inventário fitossociológico. In: L.S. SYLVESTRE and M.M.T. ROSA, eds. Manual metodológico para estudos botânicos na Mata Atlântica. Seropédica: EDUR, pp. 51-65. 